Article

\title{
Heating Performance Analysis of an Air-to-Water Heat Pump Using Underground Air for Greenhouse Farming
}

\author{
Taesub Lim ${ }^{1}$, Yong-Kyu Baik ${ }^{1, *}$ and Daeung Danny Kim ${ }^{2, *}$ \\ 1 Department of Architectural Engineering, Seoil University, Seoul 02192, Korea; francis9@seoil.ac.kr \\ 2 Architectural Engineering Department, King Fahd University of Petroleum and Minerals (KFUPM), \\ Dhahran 31261, Saudi Arabia \\ * Correspondence: ykbaik29@seoil.ac.kr (Y.-K.B.); dkim@kfupm.edu.sa (D.D.K.)
}

Received: 29 June 2020; Accepted: 27 July 2020; Published: 28 July 2020

\begin{abstract}
As one of the main businesses in Jeju-do in South Korea, specialized local products are grown in greenhouses. For greenhouse farming, it is preferable to use geothermal heat pump systems for energy conservation because of the stable temperature of the ground. In the same manner, heat pumps using underground air is recommended for greenhouse farming since underground air can easily be obtained from porous volcanic rocks in Jeju-do. However, direct usage of the underground air is not feasible for planting in the greenhouse or livestock care because the underground air is relatively humid and its temperature is low. For the present study, the heating performance of an air-to-water heat pump which used underground air as a heat source for greenhouse farming during the winter was assessed through measurements. In addition, the economic impact of the air-to-water heat pump (AWHP) was compared with a conventional air heater. According to the results, an AWHP can save more than $70 \%$ of the total heating costs compared with a conventional air heater. In sum, the utilization of the air-to-water heat pump using underground air can have a positive impact on reducing energy consumption as well as provide direct economic benefits.
\end{abstract}

Keywords: air-to-water heat pump; greenhouse; heating load; underground air

\section{Introduction}

While facing significant global warming, a lot of concerns have focused on energy use by buildings, which accounts for more than half of the total energy consumption [1,2]. Thus, a reduction in building energy consumption can lead to a reduction in $\mathrm{CO}_{2}$ emissions. According to previous studies, energy savings can be achieved by applying appropriate thermal insulation to building envelopes and the use of advanced mechanical systems [3-7]. As building occupants spend more time in an indoor environment, the importance of the selection of proper mechanical systems has become a main concern for building stakeholders regarding thermal comfort and energy conservation [8].

Among current technologies for providing both heating and cooling, heat pumps have generally applied for residential and commercial buildings by implementing demand response measures which enable one to shift building energy loads [9-11]. These systems can maintain indoor thermal comfort as well as provide a potential for energy savings in buildings by extracting energy from the air, water, and soil [12-15]. Even though heat pumps often have excessive system complexity, they have increasingly been used to building applications $[14,16]$. Among the broad range of heat pump applications, heat pump technology can also be utilized in the area of agriculture. 
According to a review article of Daghigh et al., heat pumps can be used to dry agricultural and forest products even under low-temperature conditions [17]. In addition, Kosan et al. have analyzed the efficiency of photovoltaic-thermal assisted heat pump drying systems [18]. Kumar et al. have used a closed-loop heat pump system for drying herbal leaves [19]. Besides, several studies have proposed drying methods based on heat pump technology for preserving agricultural products [20-24]. Among other applications, heat pump technology has been utilized to control the thermal performance in greenhouses. According to a study by Yang et al., the temperature in a greenhouse could be controlled by using an earth-air heat exchanger system [25]. Moreover, Ozgener and Hepbasli have studied the performance of a solar-assisted geothermal heat pump system for greenhouse heating under the climatic conditions in Turkey, where the night temperature drops to $14^{\circ} \mathrm{C}$ while the day temperature is about $31^{\circ} \mathrm{C}$ [26-28]. Ozgener has also proposed the use of a hybrid solar-assisted geothermal heat pump technology with a small wind turbine system for greenhouse heating [29].

For agricultural applications in South Korea, heat pumps have also applied to greenhouse space heating. In the case of Jeju-do in South Korea, where about $20 \%$ of the people work in agriculture cultivating local specialties like tangerines and mandarins. In the winter, these local specialties and others such as livestock and flowers are generally raised or planted in greenhouses where heating is provided by air-source heat pumps. Since the ground temperature is stable at a depth of $3 \mathrm{~m}-50 \mathrm{~m}$, it is preferable to use the ground as a heat source for both heating and cooling (i.e., geothermal heat pumps) [25,30]. Like geothermal heat pumps, air source heat pump systems using underground air are recommended for greenhouse farming. Since Jeju-do is a dormant volcano in which the geographical features consist of volcanic and sedimentary rocks, basanites, and so on, it can form underground air and water tables between rocks and sediment [31]. Thus, it is easy to obtain underground air from porous volcanic rocks, in which the underground air temperature ranges around $15{ }^{\circ} \mathrm{C}-18{ }^{\circ} \mathrm{C}$. However, the use of this underground air for planting or livestock care is not feasible because the underground air is relatively humid and its temperature is low. Most studies have investigated the performance of the air-source heat pumps and there have been few studies about air-to-water heat pumps using heat transferred from underground air. For the present study, the heating performance of an air-to-water heat pump (AWHP) system intended for use in greenhouse farming was assessed. To analyze the performance of the AWHP, the heating capacity and COP were analyzed through measurements. In addition, the economic impact of the heating performance of the AWHP for greenhouse farming was compared with a conventional air heater.

\section{Heat Transfer from Underground Air to Heat Pumps}

Figure 1 shows the schematic diagram of the AWHP. Temperature sensors were located at the underground air intake of the air/water direct contact heat exchanger, the compressor and evaporator, the fan-coil unit, and the heat storage tank. In addition, water flow meters were located at each unit of the AWHP. For the specification, the air/water direct contact heat exchanger is a cylinder of $1 \mathrm{~m}$ diameter with a height of $2.5 \mathrm{~m}$. From a borehole, underground air is drawn by the turbo blower to the air/water direct contact heat exchanger through a cylinder of $0.3 \mathrm{~m}$ diameter. Similar to the process of cooling towers, the airflow at the lower part of the heat exchanger is mixed with water sprayed from the top. In addition, this heat exchanger utilizes plastic splash type fill to enhance the contact between air and water. During the process, the heat is transferred from the humid underground air at $16{ }^{\circ} \mathrm{C}$ to water. Therefore, as a heat source, the water flow is sent to the AWHP to provide further greenhouse heating. In the AWHP, heat transferred from the air/water direct contact heat exchanger is delivered to the evaporator. Passing the compressor, water is heated at the condenser. The control system uses a Programmable Logic Controller (PLC). 


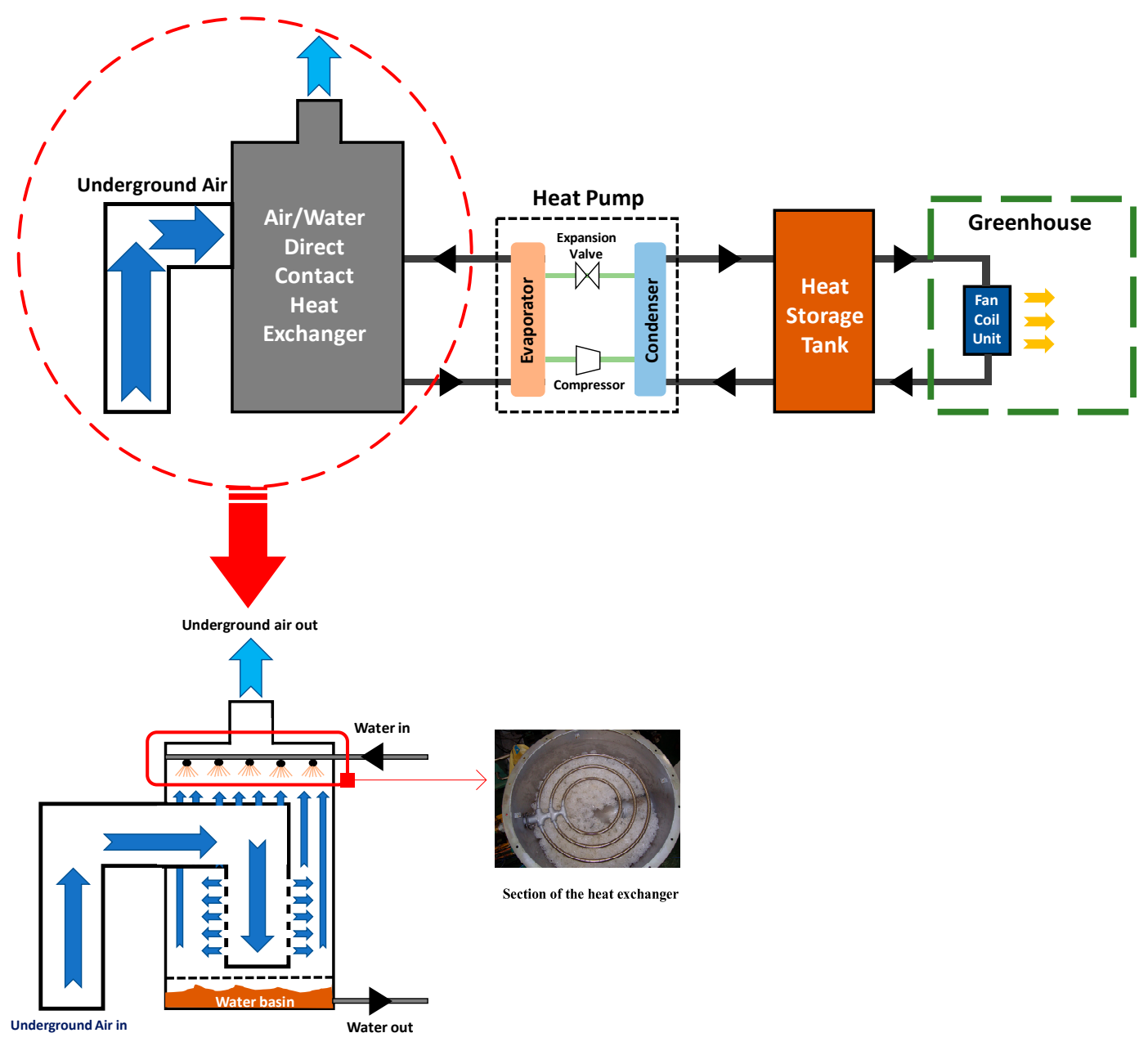

Figure 1. A schematic diagram of the AWHP.

\section{Method}

\subsection{The AWHP at the Greenhouse}

To analyze the heating performance of the AWHP, the AWHP was installed at the greenhouse for flower production located in Jeju-do in South Korea. The size of the greenhouse was $330 \mathrm{~m}^{2}$. The specifications of the AWHP are presented in Table 1.

\section{2. $C O P$ of the AWHP}

For the control of the AWHP, a blower, an air/water direct contact heat exchanger, water pumps were operated to heat or cool the water in the heat storage tank to reach the setpoint temperature. In the case that the setpoint temperature of the AWHP does not reach the heating or cooling set temperatures in the greenhouse, water pumps of the heat storage tank and the fan of the fan-coil unit were operated. To measure the Coefficient of Performance (COP) for the AWHP in a heating application, T-type thermocouples and ultrasonic flowmeters (PT868, Panametrics, Boston, MA, USA) were located at the condenser, the evaporator, and the heat storage tank. In addition, the power usage of the AWHP was measured by using a power meter (CW240, Yokogawa, Tokyo, Japan). The specifications of the equipment are presented in Table 2. 
Table 1. Specifications of the AWHP.

\begin{tabular}{|c|c|c|}
\hline \multicolumn{2}{|c|}{ Component } & Specification \\
\hline \multirow{4}{*}{ Air/water direct contact heat exchanger } & Material & Stainless steel \\
\hline & \multirow{2}{*}{$\begin{array}{c}\text { Diameter }(\mathrm{mm}) \\
\text { Height }(\mathrm{mm})\end{array}$} & 1000 \\
\hline & & 2500 \\
\hline & Heat transfer fluid & Normal water \\
\hline \multirow{5}{*}{ Heat pump } & \multirow{3}{*}{ Compressor } & High-temperature scroll type \\
\hline & & $35 \mathrm{~kW}(10 \mathrm{RT})$ \\
\hline & & 380 V (3 Phase) \\
\hline & \multirow{2}{*}{$\begin{array}{c}\text { Condenser/Evaporator } \\
\text { Refrigerant }\end{array}$} & Flat type heat exchanger \\
\hline & & R22 \\
\hline \multirow{3}{*}{ Heat storage tank } & Diameter (mm) & 2000 \\
\hline & Height (mm) & 2000 \\
\hline & Heat storage fluid & Normal water \\
\hline \multirow{2}{*}{ Turbo blower } & \multirow{2}{*}{$\begin{array}{l}\text { Capacity } \\
\text { Airflow rate }\end{array}$} & $7.5 \mathrm{~kW}$ \\
\hline & & $102 \mathrm{~m}^{3} / \mathrm{min}$ \\
\hline
\end{tabular}

Table 2. Specifications of the equipment.

\begin{tabular}{cll}
\hline & - & Non-Intrusive Liquid Flowmeter \\
PT868 & - & Velocity range: $-12.2 \mathrm{~m} / \mathrm{s}$ to $12.2 \mathrm{~m} / \mathrm{s}$ \\
& - & Accuracy: $2 \%$ \\
& - & Fluid temperature: $-40{ }^{\circ} \mathrm{C}$ to $150{ }^{\circ} \mathrm{C}$ \\
\hline & - & Voltage: $150 \mathrm{~V}$ to $1000 \mathrm{~V}$ \\
$\mathrm{CW} 240$ & - & Frequency range: $45 \mathrm{~Hz}$ to $65 \mathrm{~Hz}$ \\
& - & Accuracy: $\pm 0.2 \%$ reading \\
& - & Display interval: Approx. $0.5 \mathrm{~s}$ \\
\hline
\end{tabular}

Before calculating the COP, the heating capacity was calculated using Equation (1) below:

$$
Q_{h}=\rho_{w} \cdot V_{w} \cdot \mathcal{C}_{w} \cdot\left(T_{w, o}-T_{w, i}\right)
$$

where $Q_{h}$ is the heating capacity of the $\operatorname{AWHP}(\mathrm{kcal} / \mathrm{h}, 1 \mathrm{kcal} / \mathrm{h}=0.0012 \mathrm{~kW})$. In addition, $\rho_{w}, V_{w}$, and $c_{w}$ are water density $\left(\mathrm{kg} / \mathrm{m}^{3}\right)$, water flow $\left(\mathrm{m}^{3} / \mathrm{s}\right)$, and the specific heat capacity of water $\left(\mathrm{kJ} / \mathrm{kg}{ }^{\circ} \mathrm{C}\right)$, respectively. $T_{w, o}$ and $T_{w, i}$ are the water temperatures at the outlet and inlet of the condenser $\left({ }^{\circ} \mathrm{C}\right)$. Using Equation (2) [32], the COP was calculated for open-loop and closed-loop systems. In an open-loop system, heated water from the condenser is dumped directly to the outside, while water at the heat storage tank circulates and is reheated at the condenser and returns to the heat storage tank for a closed-loop system:

$$
C O P_{h}=\frac{Q_{h}}{P_{H P}}
$$

where $C O P_{h}$ is the COP of the AWHP for the heating application. Moreover, $P_{H P}$ is the power usage of the AWHP $(\mathrm{kW})$. To compare the heating energy consumption and temperature distributions in the greenhouse, a conventional heat pump system was also installed in the same size of the greenhouse. 


\section{Results}

\subsection{The Temperature Profiles of the System During the Condenser Operation}

It is important to figure out the relationship between the temperature changes of each component of the AWHP and the outdoor temperature conditions. The measurement results are shown in Figure 2. For the open-loop system, the heating performance was observed for $7 \mathrm{~min}$ until the water was drawn off, while it took $3 \mathrm{~h}$ to heat 6 tons of water from $18{ }^{\circ} \mathrm{C}$ to $50^{\circ} \mathrm{C}$ for the closed-loop system on 24 March 2015.
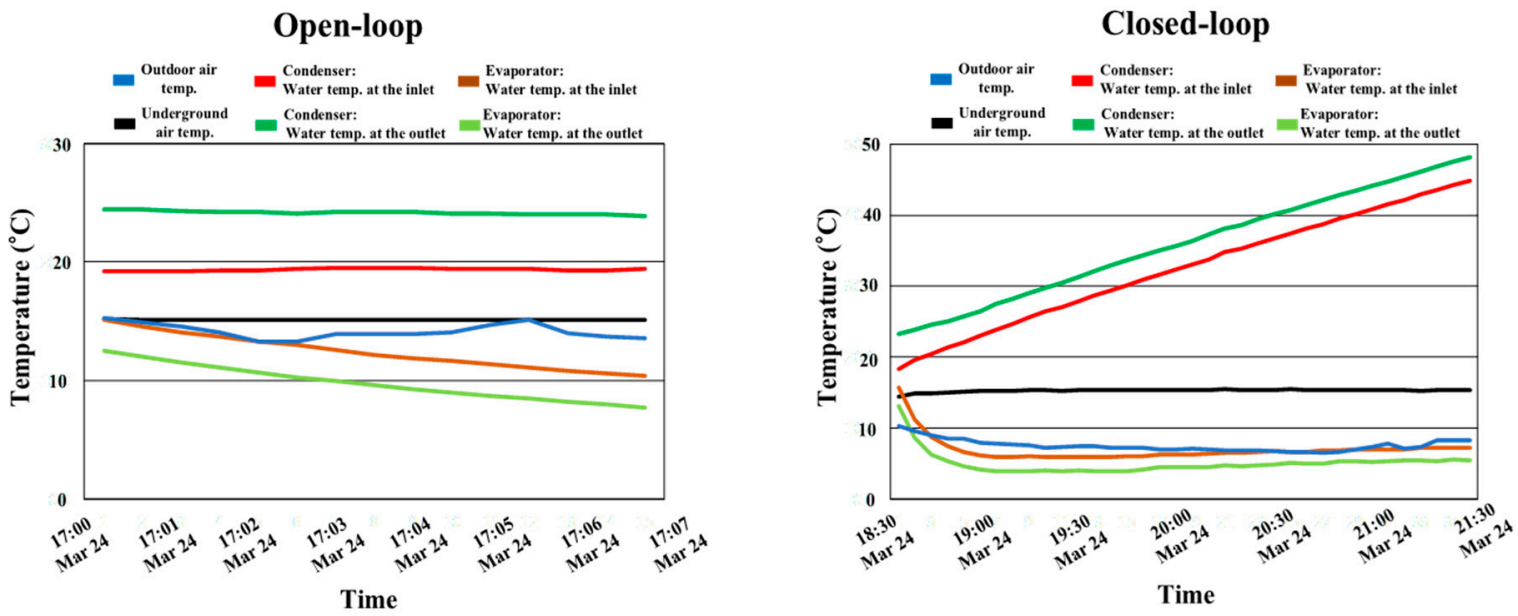

Figure 2. Temperature profiles of the system for open-loop and closed-loop application.

When measuring the water temperature of the open-loop system, the outdoor air temperature was about $13.8^{\circ} \mathrm{C}$, while the underground air temperature at the inlet of the air/water direct contact heat exchanger was maintained at $15{ }^{\circ} \mathrm{C}$. Because of the short observation, there were a little temperature changes at both inlet and outlet of the condenser. In the case of the evaporator, about a $5{ }^{\circ} \mathrm{C}$ decrease in water temperature was observed at both inlet and outlet due to the rapid water runoff. For the closed-loop system, the outdoor air temperature was slightly decreased from $10^{\circ} \mathrm{C}$ to $8{ }^{\circ} \mathrm{C}$, while the underground air temperature was also maintained at $15^{\circ} \mathrm{C}$ during the measurement. In the case of the evaporator, both water temperatures at the inlet and outlet were dropped from about $15^{\circ} \mathrm{C}$ to $5^{\circ} \mathrm{C}$ after $10 \mathrm{~min}$ from the beginning of the measurement. It was caused by the low temperature in the condenser at the early operation, which required a large amount of heat transfer. After the temperature in the condenser was increased, the amount of heat transfer was decreased. Therefore, the temperatures at the inlet and outlet of the evaporator were slightly increased to $8^{\circ} \mathrm{C}$ after the temperature was slightly increased in the condenser. Simultaneously, the underground air temperature at the outlet of the air/water direct contact heat exchanger was also increased.

\subsection{Heating Capacity for the Heating Application}

Figure 3 shows the heating capacity for the open-loop and closed-loop applications. The observed heating capacity for the open-loop and closed-loop systems was ranged from 35,000 to $41,000 \mathrm{kcal} / \mathrm{h}$ and 27,000 to $40,000 \mathrm{kcal} / \mathrm{h}$, respectively. In addition, the heat extracted by the air/water direct contact heat exchanger for the open-loop system was about $28,000 \mathrm{kcal} / \mathrm{h}$. For the closed-loop system, the extracted heat was decreased from $30,000 \mathrm{kcal} / \mathrm{h}$ to $18,000 \mathrm{kcal} / \mathrm{h}$. 

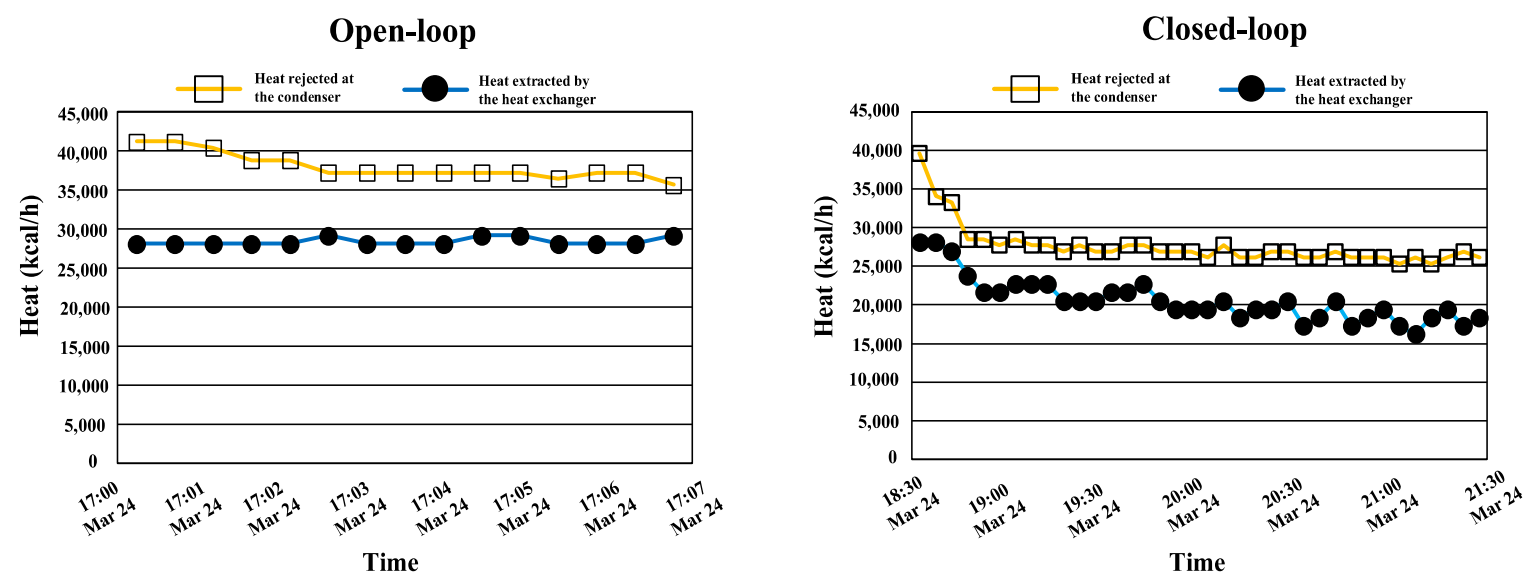

Figure 3. The heating capacity for the open-loop and closed-loop systems.

Based on the values of the heating capacity and electricity consumption, the COP values were calculated using Equation (2). As can be seen in Figure 4, the COP values were ranged from 4.3 to 5.5 for the open-loop system, while the COP value was decreased from 5.0 to 2.5 for the closed-loop system as the inlet water temperature of the condenser was increased to $50^{\circ} \mathrm{C}$. For energy consumption, the electricity usage for the open-loop system was decreased, while it was increased for the closed-loop system. It can be seen that the continuous operation of the AWHP for increasing the water temperature in the heat storage tank caused an increase in electricity consumption.
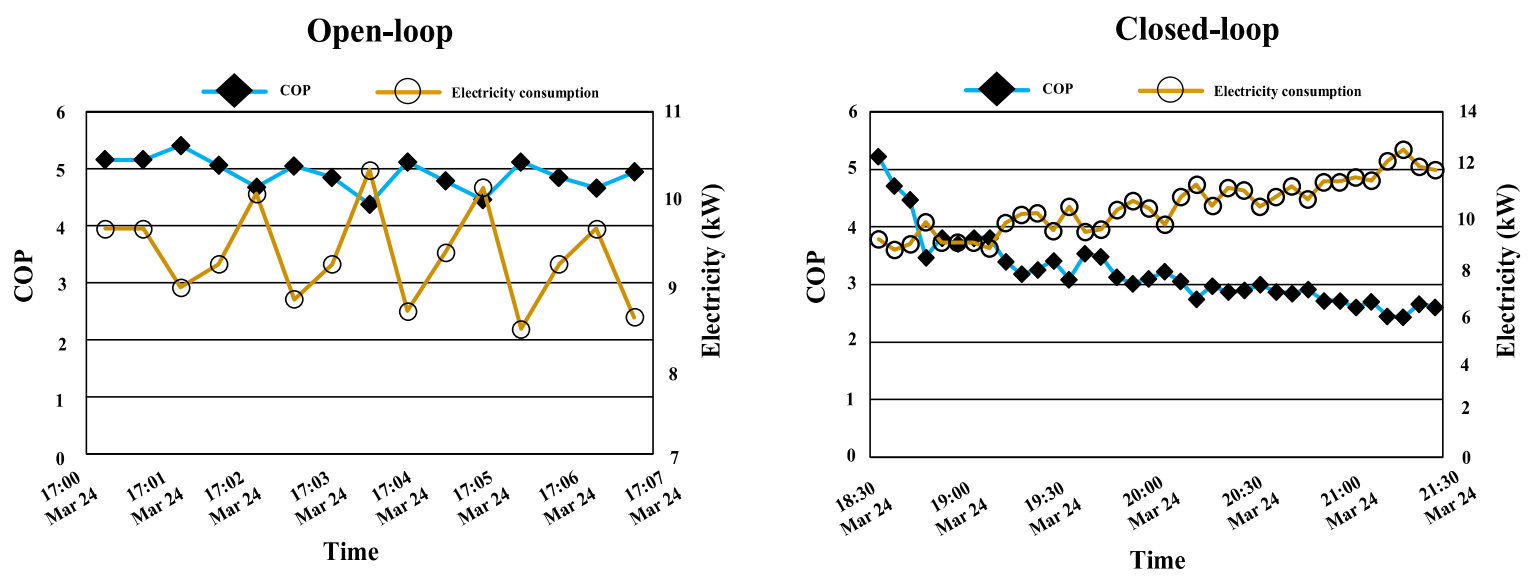

Figure 4. The COP and energy consumption for the open-loop and closed-loop systems.

Figure 5 shows the comparison of air temperature in the greenhouse operated by the AWHP and a conventional air heater. When the outdoor air temperature varied from $7{ }^{\circ} \mathrm{C}$ to $12{ }^{\circ} \mathrm{C}$ on 19 April 2015, the air temperature in the greenhouse heated by the conventional air heater was ranged from $19{ }^{\circ} \mathrm{C}$ to $26^{\circ} \mathrm{C}$, while the greenhouse heated by the AWHP showed a small air temperature fluctuation which ranged from $20^{\circ} \mathrm{C}$ to $22^{\circ} \mathrm{C}$. Based on the results, the AWHP can provide more stable heating than the conventional air heater. 


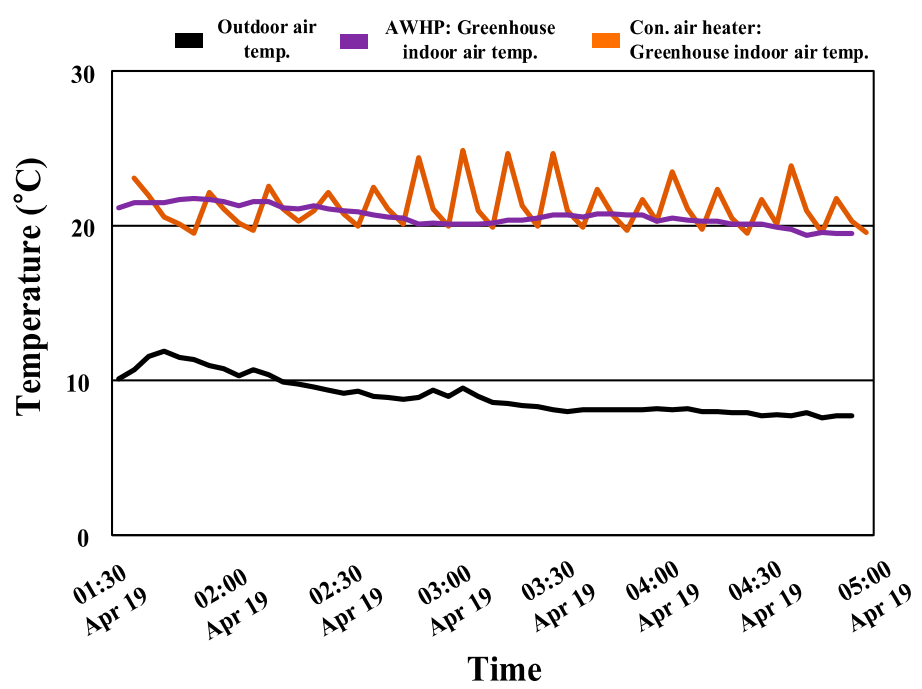

Figure 5. Comparison of heating performance between the AWHP and a conventional air heater.

\subsection{Economic Assessment of the AWHP}

To analyze the economic impact of the AWHP, the heating cost was compared with that of a conventional air heater (Table 3). Since each system used different energy sources, the total heating cost for these two systems was compared. From February to June in 2016, the AWHP consumed $4064 \mathrm{kWh} / \mathrm{m}^{2}$ of electricity at a cost of $45.5 / \mathrm{kWh}$ (South Korea Won, i.e., \$0.04 (US Dollar)). In the case of the conventional air heater, about 889.8 liters of diesel $/ \mathrm{m}^{2}$ were consumed at $\$ 840$ per liter (South Korea Won, i.e., $\$ 0.70$ (US Dollar)). As a result, the AWHP only consumed about $25 \%$ of the total heating cost of the conventional air heater.

Table 3. Heating cost comparison for the AWHP and a conventional air heater.

\begin{tabular}{ccccc}
\hline \multirow{2}{*}{ System } & \multirow{2}{*}{ Energy Consumption } & \multicolumn{2}{c}{ Total Heating Cost } & \multirow{2}{*}{ Comparison (\%) } \\
\cline { 3 - 4 } & & South Korea Won & US Dollar & \\
\hline AWHP & $4064 \mathrm{kWh} / \mathrm{m}^{2}$ (Electricity) & $\$ 184,912$ & 24.7 \\
Conventional air heater & 889.8 liters of diesel $/ \mathrm{m}^{2}$ & $\$ 747,432$ & $\$ 621$ & 100 \\
\hline
\end{tabular}

\section{Discussion and Conclusions}

As one of the main businesses in Jeje-do in South Korea, agriculture is supported by the South Korean Government. Heat pump systems using underground air are recommended for greenhouse farming, however, the direct use of underground air may harm greenhouse products because of the high humidity and low temperature of the underground air. The present study assessed the heating performance of an AWHP for greenhouses in Jeju-do through measurements. Specifically, the AWHP used the heat extracted from water in which the heat was transferred from underground air through an air/water direct contact heat exchanger.

During the measurement period, the outdoor air temperature was in the range of $7{ }^{\circ} \mathrm{C}$ to $12{ }^{\circ} \mathrm{C}$, while the underground air temperature was maintained at $15^{\circ} \mathrm{C}$. When the water temperature of the heat storage tank ranged $40{ }^{\circ} \mathrm{C}-45^{\circ} \mathrm{C}$, the COP was 2.1 to 2.7 and the heating capacity was $34.9 \mathrm{~kW}-44.2 \mathrm{~kW}$. Comparing the heating cost with the conventional air heater from February to June, the AWHP consumes about $25 \%$ of the total heating cost. 
When delivering underground air at a rate of $102 \mathrm{~m}^{3} / \mathrm{min}$, the underground air temperature dropped from $15{ }^{\circ} \mathrm{C}$ to $10{ }^{\circ} \mathrm{C}$ and $32.6 \mathrm{~kW}$ of thermal energy was obtained. This was slightly lower than that generated by conventional heat pumps since the heat energy was transferred twice through the air/water direct contact heat exchanger and the evaporator. In addition, the COP for the closed-loop system decreased from 5.0 to 2.5. Thus, it can be seen that an increase in water temperature in the heat storage tank during the early AWHP operation reduced the amount of heat absorbed by the condenser and evaporator. The heat reduction ultimately caused the AWHP to operate continuously leading to an increase in the electricity consumption of the AWHP.

Considering the outcome of the present study, the AWHP system is more energy and cost-efficient than a conventional mechanical system. Moreover, the utilization of the AWHP for greenhouse farming can reduce greenhouse gas emissions. For further study, it is necessary to find a feasible solution to increase the COP for the closed-loop application. In addition, energy-advanced or more sophisticated controlled conventional air heaters could be used for more accurate comparison with the AWHP. Furthermore, life cycle cost analysis will be conducted considering factors such as capital investments.

Author Contributions: T.L. and Y.-K.B. designed and performed the experiments; D.D.K. wrote the manuscript and analyzed the data. All authors have read and agreed to the published version of the manuscript.

Funding: This research received no external funding.

Conflicts of Interest: The authors declare no conflict of interest.

\section{References}

1. Pérez-Lombard, L.; Ortiz, J.; Pout, C. A review on buildings energy consumption information. Energy Build. 2008, 40, 394-398. [CrossRef]

2. Gonzato, S.; Chimento, J.; O’Dwyer, E.; Bustos-Turu, G.; Acha, S.; Shah, N. Hierarchical price coordination of heat pumps in a building network controlled using model predictive control. Energy Build. 2019, 202, 109421. [CrossRef]

3. Jim, C.Y. Air-conditioning energy consumption due to green roofs with different building thermal insulation. Appl. Energy 2014, 128, 49-59. [CrossRef]

4. Stavrakakis, G.M.; Androutsopoulos, A.V.; Vyörykkä, J. Experimental and numerical assessment of cool-roof impact on thermal and energy performance of a school building in Greece. Energy Build. 2016, 130, 64-84. [CrossRef]

5. Zagorskas, J.; Zavadskas, E.K.; Turskis, Z.; Burinskienè, M.; Blumberga, A.; Blumberga, D. Thermal insulation alternatives of historic brick buildings in Baltic sea region. Energy Build. 2014, 78, 35-42. [CrossRef]

6. Jiang, A.; O'Meara, A. Accommodating thermal features of commercial building systems to mitigate energy consumption in Florida due to global climate change. Energy Build. 2018, 179, 86-98. [CrossRef]

7. Hong, G.; Kim, D.D. Airtightness of electrical, mechanical and architectural components in South Korean apartment buildings using the fan pressurization and tracer gas method. Build. Environ. 2018, 132, 21-29. [CrossRef]

8. Martinez, A.; Díaz de Garayo, S.; Aranguren, P.; Astrain, D. Assessing the reliability of current simulation of thermoelectric heat pumps for nearly zero energy buildings: Expected deviations and general guidelines. Energy Convers. Manag. 2019, 198, 111834. [CrossRef]

9. D'Ettorre, F.; De Rosa, M.; Conti, P.; Testi, D.; Finn, D. Mapping the energy flexibility potential of single buildings equipped with optimally-controlled heat pump, gas boilers and thermal storage. Sustain. Cities Soc. 2019, 50, 101689. [CrossRef]

10. Clauß, J.; Georges, L. Model complexity of heat pump systems to investigate the building energy flexibility and guidelines for model implementation. Appl. Energy 2019, 255, 113847. [CrossRef]

11. Neirotti, F.; Noussan, M.; Simonetti, M. Towards the electrification of buildings heating-real heat pumps electricity mixes based on high resolution operational profiles. Energy 2020, 195, 116974. [CrossRef] 
12. Li, S.; Gong, G.; Peng, J. Dynamic coupling method between air-source heat pumps and buildings in China's hot-summer/cold-winter zone. Appl. Energy 2019, 254, 113664. [CrossRef]

13. Lozano Miralles, J.A.; López García, R.; Palomar Carnicero, J.M.; Martínez, F.J.R. Comparative study of heat pump system and biomass boiler system to a tertiary building using the life cycle assessment (LCA). Renew. Energy 2020, 152, 1439-1450. [CrossRef]

14. Potočnik, P.; Vidrih, B.; Kitanovski, A.; Govekar, E. Analysis and optimization of thermal comfort in residential buildings by means of a weather-controlled air-to-water heat pump. Build. Environ. 2018, 140, 68-79. [CrossRef]

15. Yu, Q.d. Applied research on water loop heat pump system based on a novel mechanism of energy conversion. Appl. Therm. Eng. 2019, 153, 575-582. [CrossRef]

16. Le, K.X.; Huang, M.J.; Shah, N.N.; Wilson, C.; Artain, P.M.; Byrne, R.; Hewitt, N.J. Techno-economic assessment of cascade air-to-water heat pump retrofitted into residential buildings using experimentally validated simulations. Appl. Energy 2019, 250, 633-652. [CrossRef]

17. Daghigh, R.; Ruslan, M.H.; Sulaiman, M.Y.; Sopian, K. Review of solar assisted heat pump drying systems for agricultural and marine products. Renew. Sustain. Energy Rev. 2010, 14, 2564-2579. [CrossRef]

18. Koşan, M.; Demirtaş, M.; Aktaş, M.; Dişli, E. Performance analyses of sustainable PV/T assisted heat pump drying system. Sol. Energy 2020, 199, 657-672. [CrossRef]

19. Ashok Kumar, M.; Kumaresan, G.; Rajakarunakaran, S. Experimental study of moisture removal rate in Moringa leaves under vacuum pressure in closed-loop heat pump dryer. Mater. Today Proc. 2020. [CrossRef]

20. Singh, A.; Sarkar, J.; Sahoo, R.R. Experimental energy, exergy, economic and exergoeconomic analyses of batch-type solar-assisted heat pump dryer. Renew. Energy 2020, 156, 1107-1116. [CrossRef]

21. Hasan Ismaeel, H.; Yumrutaş, R. Investigation of a solar assisted heat pump wheat drying system with underground thermal energy storage tank. Sol. Energy 2020, 199, 538-551. [CrossRef]

22. Kuan, M.; Shakir, Y.; Mohanraj, M.; Belyayev, Y.; Jayaraj, S.; Kaltayev, A. Numerical simulation of a heat pump assisted solar dryer for continental climates. Renew. Energy 2019, 143, 214-225. [CrossRef]

23. Fadhel, M.I.; Sopian, K.; Daud, W.R.W.; Alghoul, M.A. Review on advanced of solar assisted chemical heat pump dryer for agriculture produce. Renew. Sustain. Energy Rev. 2011, 15, 1152-1168. [CrossRef]

24. Tunckal, C.; Doymaz, İ. Performance analysis and mathematical modelling of banana slices in a heat pump drying system. Renew. Energy 2020, 150, 918-923. [CrossRef]

25. Yang, L.-H.; Huang, B.-H.; Hsu, C.-Y.; Chen, S.-L. Performance analysis of an earth-air heat exchanger integrated into an agricultural irrigation system for a greenhouse environmental temperature-control system. Energy Build. 2019, 202, 109381. [CrossRef]

26. Ozgener, O.; Hepbasli, A. Performance analysis of a solar-assisted ground-source heat pump system for greenhouse heating: An experimental study. Build. Environ. 2005, 40, 1040-1050. [CrossRef]

27. Ozgener, O.; Hepbasli, A. Experimental performance analysis of a solar assisted ground-source heat pump greenhouse heating system. Energy Build. 2005, 37, 101-110. [CrossRef]

28. Ozgener, O.; Hepbasli, A. Exergoeconomic analysis of a solar assisted ground-source heat pump greenhouse heating system. Appl. Therm. Eng. 2005, 25, 1459-1471. [CrossRef]

29. Ozgener, O. Use of solar assisted geothermal heat pump and small wind turbine systems for heating agricultural and residential buildings. Energy 2010, 35, 262-268. [CrossRef]

30. Ozgener, O.; Hepbasli, A. Modeling and performance evaluation of ground source (geothermal) heat pump systems. Energy Build. 2007, 39, 66-75. [CrossRef]

31. Jeju Special Self-Governing Province. Available online: https://www.Jeju.Go.Kr/ (accessed on 28 June 2020).

32. Dizaji, H.S.; Jafarmadar, S.; Khalilarya, S. Novel experiments on cop improvement of thermoelectric air coolers. Energy Convers. Manag. 2019, 187, 328-338. [CrossRef]

(C) 2020 by the authors. Licensee MDPI, Basel, Switzerland. This article is an open access article distributed under the terms and conditions of the Creative Commons Attribution (CC BY) license (http://creativecommons.org/licenses/by/4.0/). 